\title{
INDICATOR FOR URGENCY ASSESSMENT IN ERGONOMIC INTERVENTION OF WOOD HARVESTING MACHINES
}

\author{
Felipe Martins de Oliveira ${ }^{2 *} \odot$, Eduardo da Silva Lopes $^{3} \odot$, Nilton Cesar Fiedler ${ }^{4} \odot$ and Henrique Soares \\ Koehler $^{5}$ (ㅇ
}

\footnotetext{
${ }^{1}$ Received on 27.06.2019 accepted for publication on 18.02.2020.

${ }^{2}$ Faculdades FatiFajar, Departamento de Engenharia Florestal, Jaguariaíva, PR-Brasil. E-mail: <eng.oliveirafm@gmail.com>.

${ }^{3}$ Universidade Estadual do Centro-Oeste, Departamento de Engenharia Florestal, Irati, PR-Brasil. E-mail: <eslopes@unicentro.br>.

${ }^{4}$ Universidade Federal do Espírito Santo, Departamento de Engenharia Florestal, Jerônimo Monteiro, ES-Brasil. E-mail: < fiedler@ pq.cnpq.br>.

${ }^{5}$ Universidade Federal do Paraná, Departamento de Fitotecnia e Fitossanitarismo, Curitiba, PR-Brasil.. E-mail: <koehler@ufpr.br> .

*Corresponding author.
}

\begin{abstract}
Many studies on ergonomics in forestry operations are punctual and assess ergonomic variables in isolation, with each result being obtained on a specific scale. Thus, the objective of this study was to improve an ergonomic indicator through a classification according to the urgency of the ergonomic intervention, to improve its practicality of application in forest harvesting machines. This research was carried out in planted forests of a company in Southern Brazil, and based on ergonomic evaluations of a feller buncher, a skidder, a forest processor, harvesters, and forwarder machines during the day and night shifts. Vibration, noise, heat, illumination, repeatability, postures, and visibility angles were measured. The results of the ergonomic assessments were standardized by adapting the ergonomic Degree of Compliance (V) method calculated with the legislation norms, having a value between 0 and 1, and the higher the value, the greater the compliance with effective norms and guidelines. It was proposed to classify the degree of ergonomic urgency in different colors. The skidder showed the worst degrees of compliance, requiring emergency corrective measures, with an emphasis on vibrations ( $\mathrm{V} 0.0$ and 0.1 ), noise ( $\mathrm{V} 0.2$ ) and visibility in the lateral plane (V 0.0$)$ in both shifts worked due to shocks and bumps in the machine's movements and visibility difficulty in the operation, in addition to illumination ( $\mathrm{V} 0.6$ ) at night and heat ( $\mathrm{V} 0.8$ ) in the daytime. The forestry processor showed the best ergonomic performance without any urgencies but emphasizing care with noise (V 0.7 and 0.8 ) and the daily dose of vibration (V 0.8 and 0.7 ) in both shifts. The classification by a color scale made it possible to better interpret the indicators and facilitate the practical application of corrective ergonomic interventions.
\end{abstract}

Keywords: Ergonomic indicators; Forest machines; Occupational safety and health.

\section{INDICADOR PARA AVALIAÇÃO DA URGÊNCIA NA INTERVENÇÃO ERGONÔMICA DE MÁQUINAS DE COLHEITA DA MADEIRA}

RESUMO - Muitos estudos sobre ergonomia em operações florestais são pontuais e abordam isoladamente as variáveis ergonômicas, com cada resultado obtido em uma escala especifica. Objetivou-se aprimorar um indicador ergonômico por meio de uma classificação de acordo com a urgência da intervenção ergonômica, com vistas a melhorar sua praticidade de aplicação em máquinas de colheita florestal. Esta pesquisa foi realizada em florestas plantadas de uma empresa do Sul do Brasil, a partir de avaliações ergonômicas nas máquinas feller buncher, skidder, processador florestal, harvesters e forwarder, nos turnos diurno e noturno de trabalho. Mediu-se vibração, ruido, calor, iluminância, repetitividade, posturas e ângulos de visibilidade. Os resultados das avaliações ergonômicas foram padronizados pela adaptação do método do Grau de Conformidade (V) ergonômica calculado com as normas da legislação, possuindo valor entre 0 e 1 , sendo que quanto maior o valor, maior a conformidade com as efetivas normas e diretrizes. Propôs-se uma classificação do grau de urgência ergonômica em cores distintas. O skidder apresentou os piores graus de conformidade, necessitando medidas corretivas emergenciais, com destaque para vibrações $(V 0,0$ e 0,1), ruído $(V 0,2)$ e visibilidade no plano lateral $(V 0,0)$ em ambos os turnos trabalhados, em decorrência dos choques e solavancos no deslocamento da máquina e na dificuldade de visibilidade da operação, além de iluminância $(V 0,6)$ no período noturno e o calor

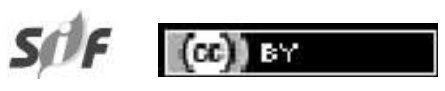

Revista Árvore 2020;44:e4428

http://dx.doi.org/10.1590/1806-908820200000028 
$(V 0,8)$ no diurno. O processador florestal apresentou o melhor desempenho ergonômico, sem emergências, porém ressaltando cuidados com ruído (V 0,7 e 0,8) e dose diária de vibração (V 0,8 e 0,7) em ambos os turnos. A classificação por meio de uma escala de cores possibilitou melhor interpretação dos indicadores e facilidade na aplicação prática das intervenções ergonômicas corretivas.

Palavras-Chave: Indicadores ergonômicos; Máquinas florestais; Saúde e segurança ocupacional.

\section{INTRODUCTION}

Mechanization in forestry operations is easily noticeable in recent decades, occurring in small, medium and large Brazilian companies. Direct benefits of this technological change include increased productivity, reduced production costs, improved quality and ergonomic conditions, as operators are less exposed to excessive physical workload and unfavorable terrain conditions, among others. However, despite the benefits arising from the greater degree of mechanization and the use of high-tech modern machines, new problems have arisen in forest machine workstations such as repetitive movements, inadequate postures, vibration and monotony.

On the other hand, it is necessary to carry out new ergonomic studies on forest machines, as works on this theme usually only contemplate the ergonomic variables individually (Fonseca et al., 2015; Häggström et al., 2016; Schettino et al., 2017), thus making it a challenge to correlate ergonomic variables. As an example, studies on machine ergonomics are cited by comparing dimensions with operators and national and international standards (Fernandes et al., 2009; Gerasimov and Sokolov, 2009; Fernandes et al., 2010; Fernandes et al., 2011; Penna et al., 2011), while studies on the working environment, vibration, noise or other interference are compared to the machine in operation (Sherwin et al., 2004; Almeida et al., 2015; Fonseca et al., 2015) and behavioral studies are concerned with the physical and mental health of the worker (Minette et al., 2008; Leite et al., 2012; Silva et al., 2013).

Despite its relevance, ergonomic evaluations carried out in isolation can make it difficult to make decisions about which area should be prioritized for ergonomic treatment, and a method which correlates the various ergonomic variables may fill this gap. In addition, each variable is commonly studied in a specific unit, such as noise in decibels, cabin space in centimeters, and visibility angles in degrees, etc. Thus, there is greater demand and complexity in interpreting results, depending on the knowledge of all the rules for decision making.

One way of simplifying the analysis and to facilitate understanding is the use of indicators, which are simplified models of reality with the ability to facilitate the understanding of phenomena, events or perceptions in order to increase the ability to communicate raw data and adapt the information to different languages and interests (Magalhães Júnior, 2007). A widely-used indicator in Brazil in the health area, but developed in Europe in the 1990s, is that derived from the Manchester Scale or Manchester Triage Scale, an internationally recognized method of screening in hospitals or emergency care, with five urgency levels associated with five different colors and waiting times for patients (Cronin, 2003). Given its due adaptations, a similar indicator could be used to prioritize ergonomic intervention through a color scale, aiming at a more practical application and understanding.

Therefore, the use of an indicator which standardizes the results of the various ergonomic variables in a single urgency scale may contribute to decision making on which variable should be a priority in corrective ergonomic treatment. If such a scale can be classified into degrees of urgency, then its applicability may be more effective and its understanding would be less complex and more comprehensive.

Having studied various tools and wood harvesting machines in the forestry area, Gerasimov and Sokolov (2014) proposed a form of integrated assessment through the indicator called "Work Severity Rate", which used the Degree of Compliance calculation (Frumkin et al., 1999) from ergonomic assessment to pre-established norms, with subsequent transformation on a scale of 0 to 6. Another form of integrated assessment was proposed by Marzano et al. (2017) through an "Ergonomic Compliance Index".

Therefore, the objective of this study was to improve an existing ergonomic indicator through a classification according to the urgency of the ergonomic intervention,

Revista Árvore 2020;44:e4428 
with a view to improve its practicality of application in wood harvesting machines.

\section{MATERIAL AND METHODS}

This research was carried out in planted forests of a company located in Southern Brazil in the State of Paraná. Several wood harvesting machines were studied in the full tree system in the city of Curiúva and cut to length system in the city of Arapoti.

The forest stands were composed by Eucalyptus grandis Hill ex Maiden species and hybrids of Eucalyptus urophylla $\mathrm{x}$ E. grandis, 8 years old, planted in slightly sloping terrain ( 3 to $8 \%$ ) with planting spacing of $3 \times 2$ $\mathrm{m}$ and Individual Average Volume (IAV) of trees of 0.4 $\mathrm{m}^{3}$. The logs were produced in assortments of $2.40 \mathrm{~m}$ in length and 15 to $17 \mathrm{~cm}$ in diameter, $2.60 \mathrm{~m}$ in length and between 18 and $22 \mathrm{~cm}$ in diameter, and $2.55 \mathrm{~m}$ in length and more than $22 \mathrm{~cm}$ in diameter.

The operations were carried out by trained and experienced operators in wood harvesting operations. Four operators per machine were evaluated in the daytime ( 8 am to $12 \mathrm{pm})$ and night shift ( $8 \mathrm{pm}$ to 12 $\mathrm{pm})$, and both the characteristics of the machines and the operators were determined (Table 1).

The study was initially submitted for analysis by a Research Ethics Committee (COMEP), approved under opinion number 2451557, with operators participating voluntarily and receiving clarifications through reading and signing the Free and Informed Consent Form (ICF) in compliance with Resolution No. 196/1996 of the National Commission for Ethics in Research (CONEP) of the Ministry of Health of Brazil.

The ergonomic variables obtained during performance of the operations were whole body vibration, noise, exposure to heat, illumination, repeatability, postures and visibility angles. Occupational full-body vibrations were collected using a whole-body vibration meter installed on machine seats, noise with the use of a dosimeter attached to operators, exposure to heat by a globe thermometer, illumination by a lux meter installed close to the implements (head or grapple), and repeatability, postures and visibility angles by images obtained by two cameras installed inside the cabins of the machines to obtain images of the profile and top operators.

The acceleration values were obtained using a Brüel \& Kjäer type 4447 whole body vibration meter, with a triaxial accelerometer ( $\mathrm{x}, \mathrm{y}$ and $\mathrm{z}$ axes) installed on the machine seat by a seat pad. Noise was measured using an Instrutherm dosimeter (model DOS-500) in the "A" compensation circuit and slow response circuit (SLOW), criterion level of $85 \mathrm{~dB}$ with an exchange rate of $5 \mathrm{~dB}$, installed in the operator's hearing zone. A Wet

Table 1 - Characteristics of wood harvesting machines and their operators.

Tabela 1 - Características das máquinas de colheita da madeira e de seus operadores.

\begin{tabular}{|c|c|c|c|c|c|c|c|}
\hline \multirow{2}{*}{\multicolumn{2}{|c|}{ Characteristics }} & \multicolumn{3}{|c|}{ Full Tree system } & \multicolumn{3}{|c|}{ Cut-to-Length system } \\
\hline & & Feller buncher & Skidder & Forest Processor & Harvester A & Harvester B & Forwarder \\
\hline \multirow{10}{*}{ Machines } & Operation & Felling & Extraction & Processing & Cutting & Cutting & Extraction \\
\hline & Wheelsets & Tracks & Tires & Tracks & Tires & Tires & Tires \\
\hline & Traction & Tracks & $6 \times 6$ & Tracks & $6 \times 6$ & $8 \times 8$ & $8 \times 8$ \\
\hline & Length (m) & 5.3 & 9.3 & 5.1 & 7.6 & 7.9 & 10.8 \\
\hline & Width (m) & 3.4 & 3.3 & 3.7 & 2.9 & 2.9 & 3.1 \\
\hline & Height (m) & 3.7 & 3.6 & 3.1 & 3.9 & 3.9 & 4.0 \\
\hline & Motor power $(\mathrm{kW})$ & 3.224 & 194 & 119 & 193 & 200 & 200 \\
\hline & Crane coupling & Side & Front & Side & Side & Front & Front \\
\hline & Implement & $\begin{array}{c}\text { Accumulator } \\
\text { head }\end{array}$ & Grapple & $\begin{array}{c}\text { Processor } \\
\text { head }\end{array}$ & $\begin{array}{c}\text { Processor } \\
\text { head }\end{array}$ & $\begin{array}{c}\text { Processor } \\
\text { head }\end{array}$ & Grapple \\
\hline & Useful life (h) & 15000 & 25000 & 18000 & 13000 & 3500 & 11000 \\
\hline \multirow{8}{*}{ Operators } & Age (years) & $39.0 \pm 13$ & $48.3 \pm 10$ & $34.5 \pm 2$ & $38.7 \pm 6$ & $38.0 \pm 2$ & $40.3 \pm 10$ \\
\hline & Stature $(\mathrm{m})$ & $1.75 \pm 0.1$ & $1.70 \pm 0.1$ & $1.77 \pm 0.1$ & $1.75 \pm 0.1$ & $1.67 \pm 0.1$ & $1.66 \pm 0.1$ \\
\hline & Body mass (kg) & $89.7 \pm 12$ & $92.0 \pm 10$ & $85.0 \pm 25$ & $79.0 \pm 5$ & $76.3 \pm 6$ & $87.0 \pm 27$ \\
\hline & Complete high school (\%) & 100 & 75 & 50 & 100 & 50 & 50 \\
\hline & Urban origin $(\%)$ & 75 & 50 & 50 & 50 & 75 & 50 \\
\hline & Right-handed (\%) & 100 & 100 & 100 & 100 & 75 & 100 \\
\hline & Company time (years) & $15.0 \pm 13$ & $15.0 \pm 8$ & $5.6 \pm 5$ & $5.5 \pm 0.7$ & $10.8 \pm 8$ & $13.0 \pm 9$ \\
\hline & Function time (years) & $8.7 \pm 6$ & $8.7 \pm 2$ & $5.1 \pm 3$ & $1.5 \pm 0.4$ & $6.4 \pm 6$ & $13.0 \pm 9$ \\
\hline
\end{tabular}


Table 2 - Limits used in the Ergonomic Indicator calculation.

Tabela 2 -Limites utilizados no cálculo do Indicador Ergonômico.

\begin{tabular}{|c|c|c|c|}
\hline Evaluated data & Limit type & Value & Method or Norm \\
\hline Whole body vibration & Maximum & $1.1 \mathrm{~m} / \mathrm{s}^{2}$ & NHO 09 \\
\hline Vibration dose of whole body & Maximum & $21 \mathrm{~m} / \mathrm{s}^{1,75}$ & NHO 09 \\
\hline Noise & Maximum & $85 \mathrm{~dB}(\mathrm{~A})$ & NR 15 (Annex 1) \\
\hline Exposure to heat & Maximum & $\mathrm{IBUTG}=30$ & NR 15 (Annex 3) \\
\hline Illumination & Minimum & 120 lux & Skogforsk \\
\hline Repeatability & Maximum & $\mathrm{SI}=7$ & Strain index \\
\hline Posture & Maximum & Score $=7$ & RULA \\
\hline Sagittal visibility angle & Maximum & 25 degrees & Skogforsk \\
\hline Side visibility angle & Maximum & 30 degrees & Skogforsk \\
\hline
\end{tabular}

Bulb Index and Globe Thermometer (IBUTG) was used to assess the occupational exposure of workers to heat, obtained by means of a Digital Thermal Stress Meter (Globe Thermometer) with a datalogger (model TGD1800), installed inside the machine cabins. Illumination was measured using a digital Luxmeter with a datalogger (model TES-1336A). Repeatability, postures and visibility angles were assessed by filming the workers during the wood harvesting operations, obtained through two ACTIA DVR cameras equipped with a recording unit with four channels installed inside the cabins of the machines. The first camera was fixed on the side in order to capture the image of the operator in profile, and the second on the cabin roof in order to capture the top view.
All ergonomic instruments for data collection were properly calibrated, having been installed concomitantly inside the cabins of the machines. All ergonomic data were collected simultaneously with the machines in real work situations in both work shifts. Twelve repetitions were performed for each variable, composed of the averages of the variables sampled over a period of 2 hours of collection for each machine, with each ergonomic variable having specific collection limits and methodologies (Table 2).

The ergonomic parameters measured in the harvesting machines are shown in Table 3.

Standardization of the results of the variables was carried out by the Ergonomic Degree of Compliance (V)

Table 3 - Ergonomic parameters measured on wood harvesting machines.

Tabela 3 - Parâmetros ergonômicos medidos nas máquinas de colheita da madeira.

\begin{tabular}{|c|c|c|c|c|c|c|c|}
\hline \multirow{2}{*}{ Shift } & \multirow{2}{*}{ Variable } & \multicolumn{3}{|c|}{ Full Tree system } & \multicolumn{3}{|c|}{ CTL system } \\
\hline & & Feller buncher & Skidder & Forest Processor & Harvester A (6x6) & Harvester B $(8 \times 8)$ & Forwarder \\
\hline \multirow{9}{*}{ Day } & AV & $0.68 \pm 0.1$ & $1.62 \pm 0.3$ & $0.47 \pm 0.1$ & $0.91 \pm 0.1$ & $0.55 \pm 0.1$ & $0.87 \pm 0.1$ \\
\hline & DV & $13.07 \pm 2.1$ & $28.71 \pm 4.1$ & $13.6 \pm 4.7$ & $18.37 \pm 3$ & $12.15 \pm 2.3$ & $19.02 \pm 3.2$ \\
\hline & $\mathrm{N}$ & $65.37 \pm 4.9$ & $88.88 \pm 2.3$ & $68.5 \pm 10.2$ & $74.24 \pm 10.4$ & $63.39 \pm 8.9$ & $71.63 \pm 10.0$ \\
\hline & $\mathrm{H}$ & $19.22 \pm 2.5$ & $20.51 \pm 2.6$ & $18.13 \pm 2.5$ & $18.02 \pm 2.6$ & $18.78 \pm 2.9$ & $20.64 \pm 3.2$ \\
\hline & I & $3142.33 \pm 466.0$ & $20000 \pm 0.0$ & $4976.62 \pm 479.8$ & $7720.13 \pm 477.2$ & $7735.21 \pm 1121.9$ & $20000 \pm 0.0$ \\
\hline & $\mathrm{R}$ & $2.81 \pm 0.3$ & $2.31 \pm 0.2$ & $3.17 \pm 0.4$ & $2.81 \pm 0.7$ & $2.38 \pm 0.3$ & $2.23 \pm 0.7$ \\
\hline & $\mathrm{P}$ & $2.5 \pm 0.5$ & $3.24 \pm 0.1$ & $2.17 \pm 0.4$ & $2.8 \pm 0.4$ & $2.49 \pm 0.4$ & $2.58 \pm 0.5$ \\
\hline & SV & $14.25 \pm 5.2$ & $11.58 \pm 4.5$ & $8.58 \pm 2.0$ & $14.08 \pm 3.9$ & $10.25 \pm 3.4$ & $11 \pm 7.2$ \\
\hline & LV & $7.75 \pm 2.4$ & $38.25 \pm 9.8$ & $8.83 \pm 2.0$ & $7.25 \pm 2.7$ & $7.33 \pm 1.8$ & $29.58 \pm 6.4$ \\
\hline \multirow{9}{*}{ Night } & AV & $0.77 \pm 0.1$ & $1.23 \pm 0.1$ & $0.55 \pm 0.1$ & $0.68 \pm 0.1$ & $0.44 \pm 0.1$ & $0.8 \pm 0.1$ \\
\hline & DV & $15.15 \pm 2.5$ & $22.11 \pm 2.3$ & $14.12 \pm 5.8$ & $12.5 \pm 1.4$ & $10.06 \pm 3.1$ & $19.06 \pm 3.6$ \\
\hline & $\mathrm{N}$ & $78.32 \pm 7.7$ & $86.83 \pm 7.4$ & $62.37 \pm 8.8$ & $63.97 \pm 9.8$ & $63.97 \pm 9.8$ & $73.45 \pm 8.0$ \\
\hline & $\mathrm{H}$ & $17.11 \pm 1.5$ & $15.25 \pm 2.0$ & $17.06 \pm 1.6$ & $15.96 \pm 2.1$ & $17.33 \pm 1.6$ & $14.62 \pm 1.8$ \\
\hline & I & $193.31 \pm 21.4$ & $144.8 \pm 17.4$ & $336.52 \pm 51.0$ & $313.72 \pm 49.4$ & $277.61 \pm 41.1$ & $202.31 \pm 26.4$ \\
\hline & $\mathrm{R}$ & $2.44 \pm 0.3$ & $2.38 \pm 0.3$ & $3.25 \pm 0.5$ & $2.56 \pm 0.4$ & $2.38 \pm 0.3$ & $2.73 \pm 0.9$ \\
\hline & $\mathrm{P}$ & $2.25 \pm 0.5$ & $3.34 \pm 0.2$ & $2.42 \pm 0.5$ & $2.99 \pm 0.3$ & $2.46 \pm 0.4$ & $2.67 \pm 0.5$ \\
\hline & SV & $7.92 \pm 2.9$ & $3.0 \pm 0.1$ & $8.92 \pm 2.1$ & $14.83 \pm 5.9$ & $8.17 \pm 1.3$ & $9.67 \pm 2.7$ \\
\hline & LV & $6.17 \pm 2.8$ & $76.83 \pm 9.8$ & $7.25 \pm 1.9$ & $7.5 \pm 2.2$ & $8.67 \pm 2.7$ & $29.42 \pm 3.1$ \\
\hline
\end{tabular}

Revista Árvore 2020;44:e4428 
method of the situation under study, being based on the rules pre-established by legislation and described by Frumkin et al. (1999). Critical limits were used for each ergonomic variable according to their respective method or standard.

The degree of compliance of the ergonomic evaluation with the pre-established standards was calculated, obtaining a value between 0 and 1 , where a value of 1 meant perfect adaptation to the norms, and the further it moved towards 0 , the worse the ergonomic condition.

The calculation was carried out according to that described by Frumkin et al. (1999), taking into account whether the standards determine a maximum possible value (Equation 1), whether they determine a minimum possible value (Equation 2) or whether they determine a possible range of compliance (Equation 3).

$$
\begin{aligned}
& \mathrm{V}=1-0,69 \times\left(\frac{\mathrm{x}}{\mathrm{x}_{\max }}\right)^{4} \\
& \mathrm{~V}=1-0,69 \times\left(\frac{\mathrm{x}_{\min }}{\mathrm{x}}\right)^{4} \\
& \mathrm{~V}=1-0,69 \times\left(\frac{\left|\mathrm{x}-0,5 \times\left(\mathrm{x}_{\max }+\mathrm{x}_{\min }\right)\right|}{0,5 \times\left(\mathrm{x}_{\max }+\mathrm{x}_{\min }\right)}\right)
\end{aligned}
$$

where: $\mathrm{V}=$ degree of compliance; $\mathrm{x}=$ value of the measured ergonomic variable; $x \min$ and $x \max =$ possible minimum and maximum value according to the standards.

The method of Frumkin et al. (1999) was changed in order to classify the ergonomic compliance into different urgency classes in the intervention to obtain more detailed trends of action. It was proposed to divide

\begin{tabular}{|c|c|c|c|c|c|c|c|c|c|}
\hline System & Machine & Period & $\mathrm{AV}$ & DV N & $\mathrm{H}$ & $\bar{I}$ & $\mathrm{R}$ & $P$ & SV LV \\
\hline \multirow{6}{*}{ Full tree } & \multirow{2}{*}{ Feller buncher } & Day & 0.9 & 0.90 .8 & 0.9 & 1.0 & 1.0 & $\overline{1.0}$ & 0.91 .0 \\
\hline & & Night & 0.8 & 0.80 .5 & 0.9 & 0.9 & 1.0 & 1.0 & $\begin{array}{ll}1.0 & 1.0\end{array}$ \\
\hline & \multirow{2}{*}{ Skidder } & Day & 0.0 & $\begin{array}{ll}0.0 & 0.2\end{array}$ & 0.8 & 1.0 & 1.0 & 1.0 & 0.9 \\
\hline & & Night & 0.0 & 0.10 .2 & 0.9 & 0.6 & 1.0 & 1.0 & 1.0 \\
\hline & \multirow{2}{*}{ Forest Processor } & Day & 1.0 & 0.80 .7 & 0.9 & 1.0 & 1.0 & 1.0 & 1.01 .0 \\
\hline & & Night & 0.9 & 0.70 .8 & 0.9 & 1.0 & 1.0 & 1.0 & 1.01 .0 \\
\hline \multirow{6}{*}{ CTL } & \multirow{2}{*}{ Harvester A (6x6) } & Day & 0.6 & 0.50 .6 & 0.9 & 1.0 & 1.0 & 1.0 & 0.91 .0 \\
\hline & & Night & 0.9 & 0.90 .7 & 0.9 & 1.0 & 1.0 & 1.0 & 0.81 .0 \\
\hline & \multirow{2}{*}{ Harvester B (8x8) } & Day & 0.9 & 0.90 .8 & 0.9 & 1.0 & 1.0 & 1.0 & 1.01 .0 \\
\hline & & Night & 1.0 & 0.90 .7 & 0.9 & 1.0 & 1.0 & 1.0 & 1.01 .0 \\
\hline & \multirow{2}{*}{ Forwarder } & Day & 0.7 & 0.50 .6 & 0.8 & 1.0 & 1.0 & 1.0 & 0.9 \\
\hline & & Night & 0.8 & 0.40 .6 & 1.0 & 0.9 & 1.0 & 1.0 & 1.0 \\
\hline
\end{tabular}
the degree of compliance into more classes as the value deviated from 1 .

Figure 1 - Need for ergonomic intervention in wood harvesting machines.

Figura 1 - Necessidade de intervenção ergonômica nas máquinas de colheita de madeira. 
In addition, it was proposed to use different colors to represent each need for ergonomic intervention to facilitate visual identification. As the intention of using colors was to associate them with urgency in the need for action, a parallel was made with the health area and the same sequence of colors used in the Manchester Triage Scale (CRONIN, 2003) was used, however with the exclusion of blue. Thus, the proposed classification was:

$\mathrm{V}=1.0$ : Green, without the need for corrective ergonomic intervention;

$\mathrm{V}=0.9$ : Yellow, not an urgent ergonomic intervention;

$\mathrm{V}=0.8$ to 0.7 : Orange, urgent ergonomic intervention;

$\mathrm{V}<0.7$ : Red, emergency.

\section{RESULTS}

Degrees of Compliance (Vs) were classified with different colors according to the urgency of the ergonomic intervention (Figure 1). This classification aimed to facilitate decision making on which ergonomic variable should be prioritized in terms of treatment.

In the full tree system, the feller buncher had the worst performance in the noise variable, with a degree of compliance $(\mathrm{V})$ of 0.5 at night, followed by noise in the daytime with an average daily dose of nighttime vibration of 0.8 . The average vibration, the vibration dose and the visibility in the sagittal plane of the day, the illumination in the night shift and the heat in both observation periods had $0.9 \mathrm{~V}$, which were not yet perfectly adequate, therefore requiring corrective ergonomic measures with little urgency.

The skidder was the machine which was most inadequate from an ergonomic point of view, with $\mathrm{V}$ equal to 0 (zero) in the average vibration and lateral visibility variables in both work shifts, in addition to the high dose of vibration in the day shift. Next, the nightshift vibration dose scored 0.1 , while the noise in both shifts scored 0.2 . Such values characterize emergency situations, where the permitted limit has been exceeded as having high severity. The variables night illumination $(\mathrm{V}=0.6)$, daytime heat $(\mathrm{V}=0.8)$ and nighttime heat $(\mathrm{V}=0.9)$, and visibility in the sagittal plane $(\mathrm{V}=0.9)$ revealed a lesser degree of severity but were considered non-compliant.
The forestry processor obtained the best degree of compliance in the ergonomic variables among the other machines of the full tree system. However, it is worth mentioning the negative value in relation to the worst value found in the daily dose of vibration at night (0.7), followed by daytime and noise at night with a $\mathrm{V}$ of 0.8 . Furthermore, the average vibration and heat in both shifts was below ideal with a V of 0.9 . It is observed that the presence of vibration is noticed even though the machine does not need to move much during its operational cycle, possibly due to the oscillations present in the transmission system and also the shocks (impacts) caused by using the implement (head or grapple) in executing the timber harvesting operations.

In the cut to length system, the $6 \times 6$ harvester presented the worst vibration dose during the day with a degree of compliance of 0.5 , followed by average vibration and noise during the day shift with a $\mathrm{V}$ of 0.6 , all being emergency situations. The variables of noise at night were 0.7 , night visibility in the sagittal plane with 0.8 and daytime with 0.9 , thus constituting less urgent ergonomic conditions.

On the other hand, the $8 \times 8$ harvester did not present such negative results, being considered the best machine in this wood harvesting system. The worst indicators for this machine remained in the noise variable with $\mathrm{V}$ of 0.7 in the night shift and 0.8 in the day shift. Then the variables of vibration in the daytime period, in addition to the daily dose of vibration and heat in both shifts remained at 0.9 .

The forwarder was the machine within the CTL system which presented the worst ergonomic performance due to the difficulties of lateral visibility, with $\mathrm{V}$ of 0.2 and 0.3 for the day and night shifts. Such values are related to the large percentage of time the workers kept their head rotated laterally in the wood loading and unloading phases, emphasizing that the machine did not have a cabin rotation. There was also daily dose of vibration with a degree of compliance of 0.5 for the daytime and 0.4 for the nighttime, while the noise presented 0.6 in both work shifts. A V of 0.9 should also be highlighted for the night illumination and the sagittal plane visibility in the daytime.

The general color classification of the need for ergonomic intervention in percentage visually facilitates identification of the wood harvesting machines in the most problematic Full tree and CTL systems (Figure 2).

Revista Árvore 2020;44:e4428 


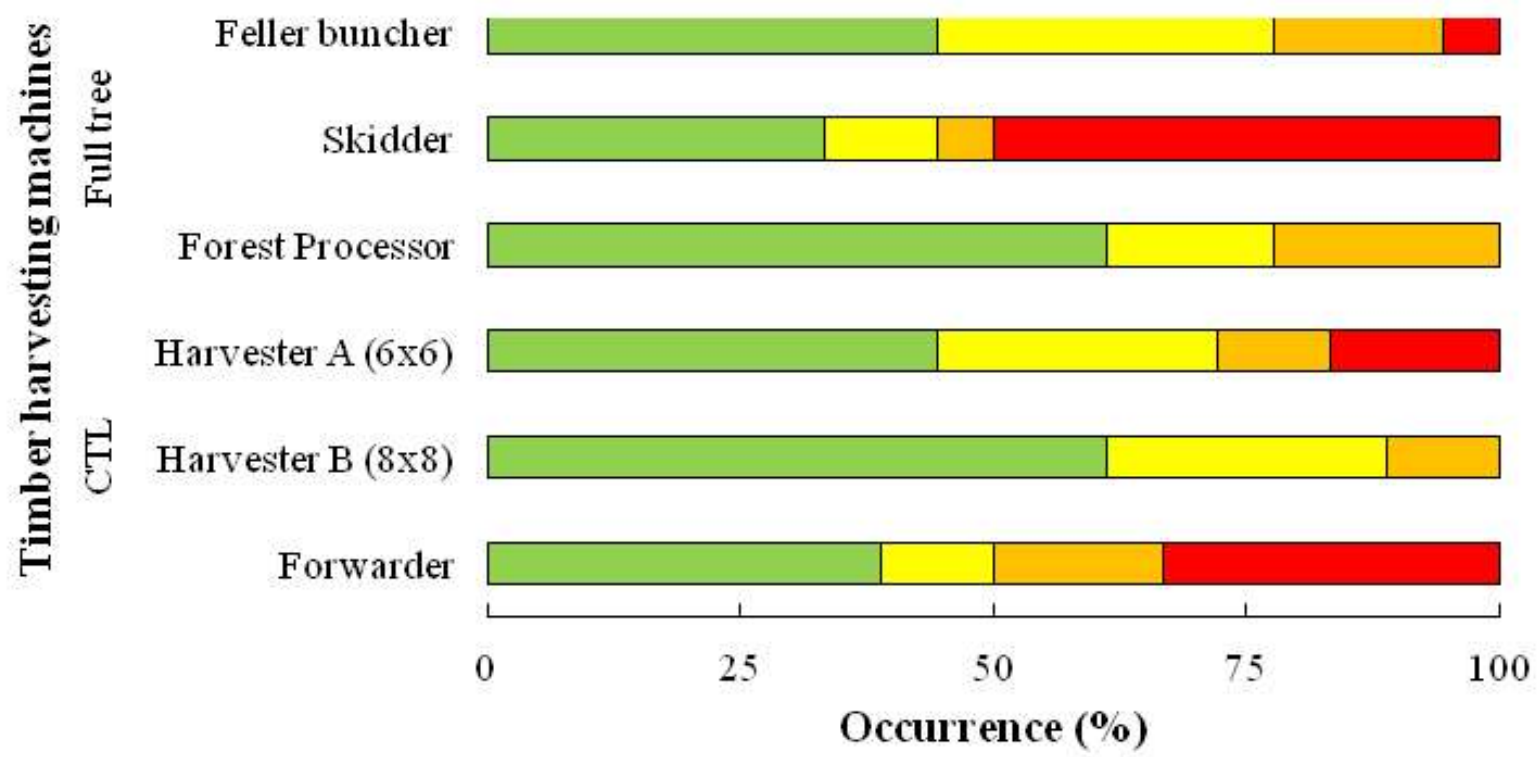

$\square$ Noneed $\square$ Noturgent $\square$ Urgent $\square$ Emergency

Figure 2 - Degrees of Compliance (V) calculated for wood harvesting machines.

Figura 2 - Graus de Conformidade (V) calculados para as máquinas de colheita da madeira.

It is clear that there is a predominance of emergency situations in both extraction machines. The worst condition was observed in the skidder, with emergency in $50 \%$ of the variables, followed by the forwarder with emergency in $33 \%$. Notably, it is possible to distinguish the best machines as the forest processor and the $8 \times 8$ harvester, both with $61 \%$ of ergonomic variables without the need for corrective intervention.

\section{DISCUSSION}

As can be seen in the results, the worst degrees of ergonomic compliance were obtained in the wood extraction machines and were mainly caused by the vibration and posture problems in the skidder and forwarder. As verified in the literature, such ergonomic variables are in fact problematic in these two wood harvesting machines (Almeida et al., 2015; Synwoldt and Gellerstedt, 2003). The vibration is mainly due to the operation from the bumps which occur during the machine's movement caused by contact of the tires with the ground; in contrast, the inadequate postures are usually caused by failures in the design of the machine concepts, both external, such as the location of the hydraulic crane, the hoses, as well as inside the workstations, such as the vertical columns. Thus, it is observed that ergonomic improvements of both variables must be carried out in part by operational corrections, such as reducing the travel speed and extraction on better operating tracks, but also in part by design corrections such as narrower columns for a larger visual field.

The noise of the feller buncher at night stands out in the full tree system which presented an emergency in the ergonomic intervention, followed by urgency regarding the noise and the vibration at night.

However, it was evident that the priority machine for an ergonomic readjustment was the skidder, because more than half of the analyzed variables had an emergency need, with a negative emphasis on vibrations, noise and visibility in the lateral plane in both work shifts, and the illumination at night. In addition, the heat observed during the day resulted in the need for urgent ergonomic intervention.

Therefore, performing the operation under these conditions is inadmissible, and immediate corrective

Revista Árvore 2020;44:e4428 
measures must be taken to protect the occupational health of operators and eliminate this ergonomic emergency. Replacement of this machine by another which provides better ergonomic conditions to operators with a rotation system for the cabin and improvements in the operations planning to reduce vibrations caused by shocks and bumps in the movement of the machine are possible measures to be taken by forest managers.

The forestry processor was the minor problematic machine from the ergonomic point of view with no emergency to be taken, however having urgency in the daily dose of vibration and noise above the limit allowed in both work shifts. Even though there was no emergency situation, the mentioned variables deserve to be highlighted due to the special treatment that must be provided to reduce the severity of both ergonomic variables.

In the cut to length system, the $6 \times 6$ harvester presented an emergency situation during the day in relation to vibration and noise. Also, the visibility in the sagittal plane presented urgency in need of corrective actions. These circumstances must be readjusted immediately to improve working conditions for operators. On the other hand, the $8 \times 8$ harvester was considered as needing minor readjustment, however it presented an urgency for intervention in the noise variable in both work shifts. Posture, repetitiveness, illumination and visibility in the lateral plane stand out as positive variables in the operation with this machine.

The forwarder presented a priority need for intervention among the machines in both wood harvesting systems, being considered the most inadequate with an emergency situation in relation to the daily dose of vibration, noise and visibility in the lateral plane. When analyzing the ergonomic variables in the extraction operation with the forwarder, it is highlighted that the most inadequate observed among all was the noise, having shown emergency or urgency in the need for ergonomic intervention on all machines in both work shifts studied. Even though they were below 85 $\mathrm{dB}(\mathrm{A})$ as prescribed by the Brazilian legislation NR-15, values very close to the limits can be classified slightly below 1 , indicating that even with little urgency in the intervention, these should be monitored more carefully in order to avoid possible problems.

In the evaluation of ergonomic indicators in forest machines, Gerasimov and Sokolov (2014) also found extreme working conditions in the extraction of wood with skidders caused by noise and visibility problems, constituting a similar situation to that obtained in this study. However, it is noteworthy that such researchers classified the studied forwarders as "comfortable" or at most "relatively uncomfortable", while in this study it was the second machine in the emergency order for ergonomic interventions.

On the other hand, Marzano et al. (2017) evaluated two machines (harvester and forwarder) for proposing an ergonomic index for forest machines. The authors concluded that their proposed method for determining what they called the "Ergonomic Compliance Index" was efficient in evaluating both machines as it enabled establishing a comparison between them.

\section{CONCLUSIONS}

The use of the indicator proposed in this study enabled identifying the best and the worst machines in performing wood harvesting operations regarding ergonomic variables, and the classification of the results on a color scale enabled better interpretation of the ergonomic indicators, facilitating identification of priority variables for corrective intervention.

The proposed method made it possible to identify the skidder as the wood harvesting machine with the worst ergonomic problems in performing the operation due to the vibrations caused by the bumps which occurred while moving through the field, the noise emitted by the machine, the impaired visibility and the inadequate posture adopted by the operator in the lateral plane when loading the wood.

Noise was the variable which most affected the ergonomic performance of wood harvesting machines, with an emergency or urgent need for ergonomic intervention.

The posture and repeatability variables were the only ones which did not require ergonomic intervention in any of the evaluated machines or periods studied, mainly due to the cabin rotation systems; however, the evaluation must be carried out in conjunction with the visibility angles, which pointed out problems on the extraction machines for lateral visibility.

The best ergonomic results when carrying out the operations were obtained in the $8 \times 8$ harvester and in the forest processor without emergency during the work

Revista Árvore 2020;44:e4428 
shifts, mainly caused by the little displacement during the wood cutting and processing activities, and by the good visibility provided by the machine cabins.

\section{REFERENCES}

Almeida SF, Abrahão RF, Tereso MJA. Avaliação da exposição ocupacional à vibração de corpo inteiro em máquinas de colheita florestal. Cerne. 2015;21(1):1-18.

Cronin JG. The introduction of the Manchester triage scale to an emergency department in the Republic of Ireland. Accident and Emergency Nursing. 2003;11(2):121-25.

Fernandes HC, Brito AB, Minette LJ, Leite DM, Leite ES. Aplicação de índices ergonômicos na avaliação da cabine de um trator florestal "fellerbuncher”. Scientia Forestalis. 2011;39(90):273-81.

Fernandes HC, Brito AB, Minette LJ, Santos NT, Rinaldi PCN. Avaliação ergonômica da cabine de um trator florestal. Revista Ceres. 2010;57(3):307-14. doi: doi.org/10.1590/S0034-737X2010000300004

Fernandes HC, Brito AB, Santos, NT, Minette LJ, Rinaldi PCN. Análise antropométrica de um grupo de operadores brasileiros de "feller-buncher". Scientia Forestalis. 2009;37(81):17-25.

Fonseca A, Aghazadeh F, Hoop C, Ikuma L, Al-Qaisi S. Effect of noise emitted by forestry equipment on workers' hearing capacity. International Journal of Industrial Ergonomics. 2015;46:105-12. doi: doi.org/10.1016/j. ergon.2014.05.001

Frumkin AA, Zinchenko TP, Vinokurov LV. Методы И Средства Эргономического Обеспечения Проектирования (Methods and means of ergonomics during design). Saint-Petersburg: Transport University; 1999. ISBN 9785764100418.

Gerasimov Y, Sokolov AYa. Ergonomic characterization of harvesting work in Karelia. Croatian Journal of Forest Engineering. 2009;30(2):159-70.

Gerasimov Y, Sokolov A. Ergonomic evaluation and comparison of wood harvesting systems in Northwest Russia. Applied ergonomics. 2014;45(2):318-38. doi: doi.org/10.1016/j.apergo.2013.04.018
Häggström C, Öhman M, Burström L, Nordfjell T, Lindroos O. Vibration Exposure in Forwarder Work: effects of work element and grapple type. Croatian Journal of Forest Engineering. 2016;37(1):107-18.

Leite AMP, Soares TS, Nogueira GS, Peña SV. Perfil e qualidade de vida de trabalhadores de colheita florestal. Revista Árvore. 2012;36(1):161-68. doi: doi.org/10.1590/S0100-67622012000100017

Magalhães Júnior AP. Indicadores ambientais e recursos hídricos: realidade e perspectivas para o Brasil a partir da experiência francesa. Rio de Janeiro: Bertrand Brasil; 2007. ISBN 9788528612462.

Marzano FLC, Souza AP, Minette LJ. Proposal for an ergonomic conformity index for evaluation of harvesters and forwarders. Revista Árvore. 2017;41(4):1-8. doi: doi.org/10.1590/180690882017000400001

Minette LJ, Souza AP, Silva EP, Medeiros NM. Postos de trabalho e perfil de operadores de máquinas de colheita florestal. Revista Ceres. 2008;55(1):66-73.

Penna ES, Machado CC, Souza AP, Silva E, Silva EN. Avaliação ergonômica de modelos de cabos aéreos utilizados na extração florestal. Revista Árvore. 2011;35(3):565-71. doi: doi.org/10.1590/ S0100-67622011000300019

Schettino S, Campos JCC, Minette LJ, Souza AP. Work precariousness: ergonomic risks to operators of machines adapted for forest harvesting. Revista Árvore. 2017;41(1):1-9. doi: 10.1590/180690882017000100009

Sherwin LM, Owende PMO, Kanali CL, Lyons $\mathrm{J}$, Ward SM. Influence of tyre inflation pressure on whole-body vibrations transmitted to the operator in a cut-to-length timber harvester. Applied Ergonomics. 2004;35(3):253-61. doi: doi. org/10.1016/j.apergo.2004.02.002

Silva EP, Minette LJ, Souza AP, Marçal MA, Sanches ALP. Fatores organizacionais e psicossociais associados ao risco de LER/DORT em operadores de máquinas de colheita florestal. Revista Árvore. 2013;37(5):889-95. doi: doi.org/10.1590/S010067622013000500011

\section{Revista Árvore 2020;44:e4428}


Synwoldt U, Gellerstedt S. Ergonomic initiatives for machine operators by the Swedish logging industry.
Applied Ergonomics. 2003;34(2):149-56. doi: doi. org/10.1016/S0003-6870(03)00006-1

Revista Árvore 2020;44:e4428 